\title{
STRATEGIC MANAGEMENT DEVELOPMENT: THE ROLE OF THE LEARNING SCHOOL IN THE PROMOTION OF THE COMPETENCE OF MANAGERS
}

\author{
DESARROLLO DE LA GESTIÓN ESTRATÉGICA: EL PAPEL DE LA ESCUELA DE \\ APRENDIZAJE EN LA PROMOCIÓN DE LA COMPETENCIA DE LOS GERENTES
}

\author{
Yashar Salamzadeh ${ }^{1}$ \\ Mehran YousefNia ${ }^{2}$ \\ Mirjana Radovic Markovic ${ }^{3}$ \\ Aidin Salamzadeh ${ }^{4}$
}

\begin{abstract}
The aim of this study was to research the effects of using the Learning School to improve competency criteria of managers in Bank Saderat Iran and determine the effect of each criterion of this school. By using a Morgan table and assuming an unlimited population size, 384 individuals were randomly selected. After choosing six core competencies of the managers, data was collected using a 47-item questionnaire. After confirming the questionnaire's validity using SPSS and a Spearman's test, the significant correlation of all criteria was established, excepting for personality traits and the implementation of the learning school. Finally, using the Topsis method, criteria was ranked as follows: attitude, knowledge, capability and personality traits (directly proportional). The results of this study can be used in the decision-making process for the selection, appointment and improvement of senior managers in economic organizations in the country.
\end{abstract}

Doi: http://dx.doi.org/10.15359/eys.21-50.4

Fecha de recepción: 11-11-2016. Fechas de reenvíos: 19-12-2016 / 20-12-216. Fecha de aceptación: 21-12-2016. Fecha de publicación: 26-12-2016.

${ }^{1}$ Senior Lecturer, Farabi Institute of Higher Education, Mehrshahr, Iran. E-mail: yasharsalamzadeh@gmail.com

${ }^{2}$ MA, Farabi Institute of Higher Education, Mehrshahr, Iran. E-mail: mehran.yousefnia@mail.com

${ }^{3}$ Full Professor, Institute of Economic Sciences, Belgrade, Serbia. E-mail: mradovic@gmail.com

${ }^{4}$ PhD researcher, Faculty of Entrepreneurship, University of Tehran, Tehran, Iran. E-mail: salamzadeh@ut.ac.ir

Salamzadeh, YousefNia, Markovic \& Salamzadeh

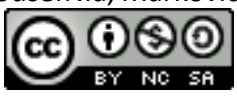

Revista Economía y Sociedad by Universidad Nacional is licensed under a CreativeCommons Reconocimiento-NoComercial- 
Keywords: strategic management; strategy schools; learning school; managers competency

\section{Resumen}

El objetivo de este estudio es investigar los efectos del uso de la escuela de aprendizaje con el fin de mejorar los criterios de competencia de los gerentes en Bank Saderat Irán y determinar los efectos de cada criterio de esta escuela. Mediante el uso de la tabla de Morgan y asumiendo el tamaño ilimitado de la población, 384 personas fueron seleccionadas al azar. Después de seleccionar seis competencias básicas de los directivos, se recogieron los datos en un cuestionario con 47 preguntas. Después de confirmar la validez del cuestionario con SPSS y con la utilización de la prueba de Spearman, se estableció la correlación significativa de todos los criterios, excepto los rasgos de personalidad y la implementación de la escuela de aprendizaje. Finalmente, se empleó el método de Topsis para ordenar los criterios de la siguiente manera: actitud, conocimiento, capacidad y rasgos de personalidad (directamente proporcional). Los resultados de este estudio se pueden utilizar en la toma de decisiones para la selección, nombramiento y mejora de los altos directivos en las organizaciones económicas del país.

Palabras claves: dirección estratégica; escuelas de estrategia; escuela de aprendizaje; competencia de gerentes

\section{Introduction}

The strategic management is an important part of organizations in today's dynamic and competitive environment that consists of three separate and interconnected processes, including: strategic planning, strategy implementation and strategic control. The resulting research in organizations shows that the most important part is strategy implementation which is closely related with the success of managers, employees and their organizations (Mišanková \& Kočišová, 2014). Henry Mintzberg, Bruce Strand and Joseph Lampel are among theorists of strategy who presented ten primary schools in the implementation of strategy. One of these schools is the Learning School. From the perspective of this school, strategy appears in the performance of everyone in organization, but often is achieved through a coordinated effort in phenomena learning as well as in dealing with their nature (Quaye, Osei, Sarbah, \& Abrokwah, 2015). H.G. Wells in few years ago predicted that the human history is moving towards close race training and managers in corporate and public institutions are at the forefront of the competition. There are complex issues that need not only firmness but also creativity, not only 2

Salamzadeh, YousefNia, Markovic \& Salamzadeh

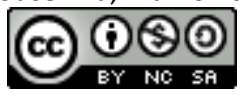

Revista Economía y Sociedad by Universidad Nacional is licensed under a CreativeCommons Reconocimiento-NoComercialCompartirlgual 4.0 Internacional License. Creado a partir de la obra en http://www.revistas.una.ac.cr/index.php/economia 
managerial control but also managerial perspectives, not only technical skills necessary to achieve the organizational mission but also the integrity of dispute settlements in shaping the organizational mission (Khajeheian, 2013).

From the perspective of management development, the ability of organizations to survive and thrive in complex and dynamic environments is continuously dependent on the capabilities and competencies of learner managers (Kolb, Lublin, Spoth \& Baker, 1986). Currently, the competence has become a multi-functional term with different meanings that is used in various scientific fields (Mojab, Zaefarian, \& Dazian, 2011). In fact, competencies are a set of knowledge, characteristics, attitudes and skills related to each other that have great influence on peoples' job. Competences are correlated with individual's performance and they can be evaluated with acceptable standards and can be improved through training and development of the management skills as first-hand are acquired by observing what happens in practice (Chyung, Stepich \& Cox, 2006). Since it is very difficult to nurture these skills in the classroom, they are left to be grown during the work. In the learning school, strategies emerge when the employees, sometimes individually and often collectively decide that learn about situation and their organization's ability in dealing with that situation (Mintzberg, Ahlstrand, \& Lampel, 1998).

For the realization of the idea of strategic management development, understanding the needs and job requirements of managers are very important. In this context, understanding the managerial roles and necessary competencies in planning training requirements has a special place (Mumford, 1984). One of the most important of managers' competence is the competency of deep and active learning resulting from experiences and in this regard, understanding the knowledge and development of managers' competences is inevitable (Bucur, 2013). On the other hand, the learning school is considered a spontaneous phenomenon that is emerged throughout the organization and in many cases gradually evolves during the course implementation. In this school, the strategy in organization is emerged as a result of trial and error based learning within the organization. The originality of this opinion is learning. This learning to adapt with environmental conditions becomes important. Also, it must be noted to this issue that manager as formal representative of organization to coordinate and enhance the effectiveness is placed on top of it and the success of organization in achieving the goals depends on how it is managed. The effectiveness of managers also depends on their competences, skills, knowledge, insight and abilities (Chyung et al., 2006).

Therefore, regarding the necessity and importance of the issue and the extensive use of managers' competences in access to organizational strategies also necessity to identify the correct criteria for application in human resource management subsystems, the role of using learning school as one of strategy schools on improving the competency of managers which is rarely discussed in the extant research (e.g. see, Liljenberg, 2015), is selected as a research topic. The main contribution of this study is therefore that after introduction of the learning school, as one of ten strategy schools, its effect on competence indicators of managers, which

Salamzadeh, YousefNia, Markovic \& Salamzadeh

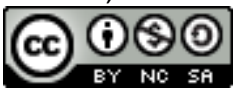

Revista Economía y Sociedad by Universidad Nacional is licensed under a CreativeCommons Reconocimiento-NoComercialCompartirlgual 4.0 Internacional License.

Creado a partir de la obra en http://www.revistas.una.ac.cr/index.php/economia 
is considered as one of important factors of organizational successes, is investigated. Then, this study stands among the very first studies in this field, which scrutinizes this relationship. Moreover, the theory is studied in a new context (Whetten, 1989), which adds to the level of contribution of this work. The study was conducted at various levels of a vanguard bank in Iran- i.e. the Saderat Bank- in order to investigate the learning school and its influence on the improvement of managers' competency. The study population included all executive, middle and senior managers in the bank in Tehran. By using Morgan's table, assuming the infinite population the sample size (confidence level of $95 \%$ and error level of $5 \%$ ) were determined to be 362. Thus, 384 individuals were randomly selected. Then, the effect of learning school on six core managerial competencies is analyzed and the items are ranked accordingly.

\section{Definitions}

\subsection{Strategy}

The definitions of strategy in order to decide about a good manager in different situations to achieve successful business are presented (Poisson-de Haro \& Turgut, 2012; Salamzadeh \& Kawamorita Kesim, 2015). The strategy is an overall plan that shows the way to achieve its business goals. The strategic decisions help the managers to evaluate changes in the external environment the effective strategy allows to optimize the use of their organizational resources, and creates the ability to extract opportunities and to limit threats in order to achieve competitive advantage. The strategy can be defined in different ways. Each strategy has unique concept and content, but in general, strategy process in three phases is defined: analysis, formulation, implementation (Abraham et al., 2015), as shown in Figure 1.

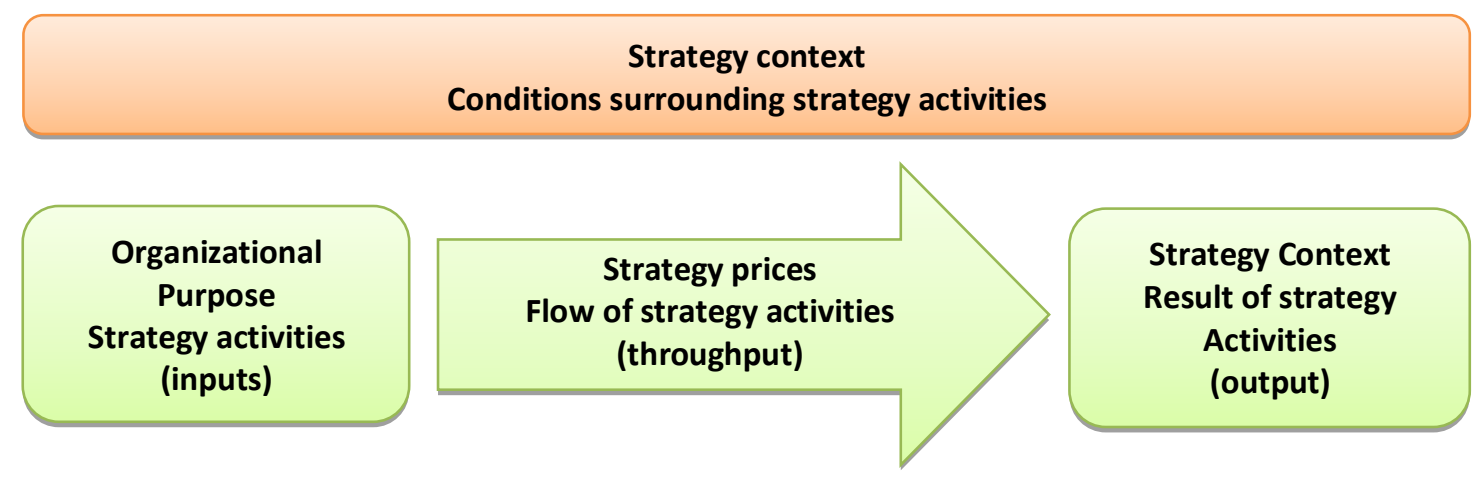

Figure 1. Strategy context, process and content, linked to organizational purpose

4

Salamzadeh, YousefNia, Markovic \& Salamzadeh

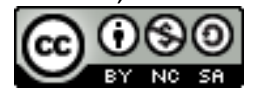

Revista Economía y Sociedad by Universidad Nacional is licensed under a CreativeCommons Reconocimiento-NoComercialCompartirlgual 4.0 Internacional License.

Creado a partir de la obra en http://www.revistas.una.ac.cr/index.php/economia 
2.2. Strategic management

Strategic management is associated with survival and growth of organizations (Bao, 2015); it includes a set of managerial decisions and actions that determine the long-term performance of organizations (Peleckis, 2015). Indeed, implementation of strategy as part of strategic management plays an important role in success of organizations. Any strategy reflects the idea that organizational goals can be achieved through it. However, defining a strategy is not an easy task; just like formulation of strategy and goals associated with it to achieve business strategic goals. The organizational competitiveness is correlated with flexible strategies. The organizations will not be able to compete in long-term, and without the appropriate strategy, the strategic development will not be successful (Mišanková \& Kočišová, 2014). Mintzberg et al. (1998) suggests that the managers rather than waiting to collect information on their office should act directly in order to achieve real strategic information (Jennings, 2002).

\subsection{The learning organization}

Learning is a classified communication that is informed and communicated through speech, talks, goals, beliefs, feelings and intentions that resolves conflicts. The approach of a learning organization is being supportive of self-learning process of management (McHugh, Groves, \& Alker, 1998). The basic situation of companies is not unrelated to quickly adapt with changes in external conditions and learning from information available in the organization (Beveridge, Gear, \& Minkes, 1997). Still, the integrated learning is presented as supplement of the gap between science and practice. An open system transfers knowledge and learning, in management under integrated network (Kolb et al., 1986); thus, learning in practice gradually increases participation in the organization. Senge (1992) introduces the major core of learning organization based on five learning fields. These five fields are summarized as follows: (i) The personal mastery: individuals should extend their personal capacities in order to create results that they tend to it, (ii) The mental models: that include the concept of environment and personal decisions and activities, (iii) the common perspective: that includes creating a sense of commitment in special working groups, developing the images of common and desirable future and principles and procedures of guiding and supporting the future, (iv) Team learning: It includes intellectual skills of a group of individuals whose talent, intelligence and ability are more than others, and ( $v$ ) System thinking: It helps managers and employees how to effectively change the system (Abraham et al., 2015).

Salamzadeh, YousefNia, Markovic \& Salamzadeh

\section{(c) (i) 8 (2)}

Revista Economía y Sociedad by Universidad Nacional is licensed under a CreativeCommons Reconocimiento-NoComercial- 


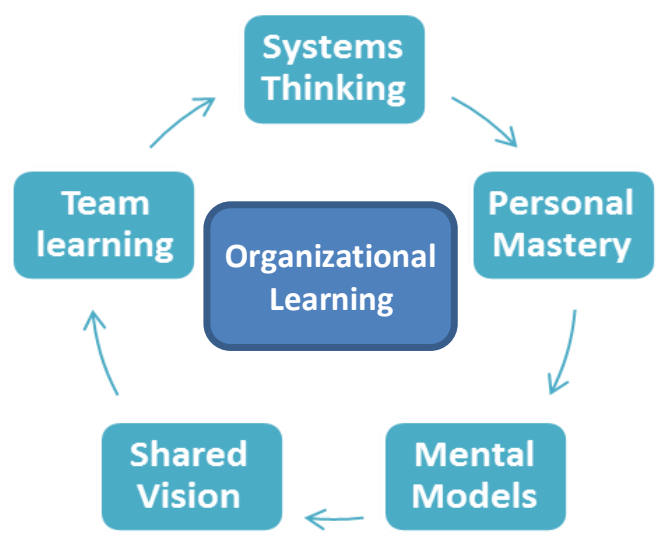

Figure 2. Major issues in learning organizations (elaborated from Senge's (1992))

\subsection{Competency}

McClelland (1976) introduces competency as a key feature in the elite performance. The competency is determined from comparing individual performances and their functional classification (Cheng, Li, Love and Irani, 2004). There are two different models are in competency concept. The American approach defines and depicts the competency as fundamental traits which are descriptive models. Another approach believes that to determine the competency a set of standards and practices is required. Boam, Sparrow, Burgoyne and Silver and several experts know competency as the best measure of evaluating the education output. Training and performance evaluation is driver of competence in the approach. The term competency is multi-faceted and some define it as special performance in individuals. Some individuals know that it consists a set of multi functions. In any case, the issue is common in all definitions of competency is that it improves the performance of individuals in workplace (Hoffmann, 1999). According to what was said, there is a correlation between individual competency and certain standards in knowledge and their understanding (Lane \& Robinson, $\underline{1995})$.

\subsection{The managerial competencies}

One of the most important competencies for learning in organizational mangers is creating hierarchical organization (Lombardo \& Eichinger, 2004). The most important competencies are derived indirectly from the intelligent individuals (Gottfredson, 2002). In fact, the Competency and practical intelligence are two concepts related together. In order to make improvements in the individual's performance, all capabilities can be used, but the most useful is learning competency (Bucur, 2013). Indeed, the five key competencies for middle-level managers, include accountability, team building, relationship management, continuous learning and conflict management (Qiao \& Wang, 2009)

6

Salamzadeh, YousefNia, Markovic \& Salamzadeh

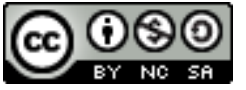

Revista Economía y Sociedad by Universidad Nacional is licensed under a CreativeCommons Reconocimiento-NoComercialCompartirlgual 4.0 Internacional License. Creado a partir de la obra en http://www.revistas.una.ac.cr/index.php/economia 
Table 1.

Core competencies (Self elaborated)

\begin{tabular}{|c|c|}
\hline Core Competencies & Description \\
\hline Results Orientation & $\begin{array}{l}\text { Individuals demonstrating this competency drive for improvement of business } \\
\text { results }\end{array}$ \\
\hline Strategic thinking & $\begin{array}{l}\text { Individuals demonstrating this competency think beyond their own areas This } \\
\text { competency requires complex thinking abilities, incorporating both analytical } \\
\text { and conceptual abilities. }\end{array}$ \\
\hline $\begin{array}{l}\text { Influence and } \\
\text { Collaboration }\end{array}$ & $\begin{array}{l}\text { Individuals demonstrating this competency are effective in working with peers, } \\
\text { partners and others who are not in the line of command, to positively impact } \\
\text { business performance. }\end{array}$ \\
\hline Team leadership & $\begin{array}{l}\text { Individuals demonstrating this competency can focus, align and build effective } \\
\text { groups. This competency includes leadership roles in cross functional, cross- } \\
\text { organizational or projects teams as well as conventional line or staff } \\
\text { management positions. }\end{array}$ \\
\hline Transformational & Individuals demonstrating this competency drive for improvement through \\
\hline Leadership & $\begin{array}{l}\text { Individuals, transforming and aligning an organization in a new and challenging } \\
\text { direction. }\end{array}$ \\
\hline Learning & $\begin{array}{l}\text { Individuals demonstrating this competency drive for improvement and } \\
\text { achievement of knowledge from each situation and experience, despite failure } \\
\text { or success. }\end{array}$ \\
\hline Motivation for career & This is not a competency but is the energy for all the competencies. \\
\hline
\end{tabular}

The successful managers need the ability to effectively understand and apply management principles and modern techniques. The experimental learning is an ideal method for managerial learning particularly for use in business strategy (Poisson-de Haro \& Turgut, 2012).

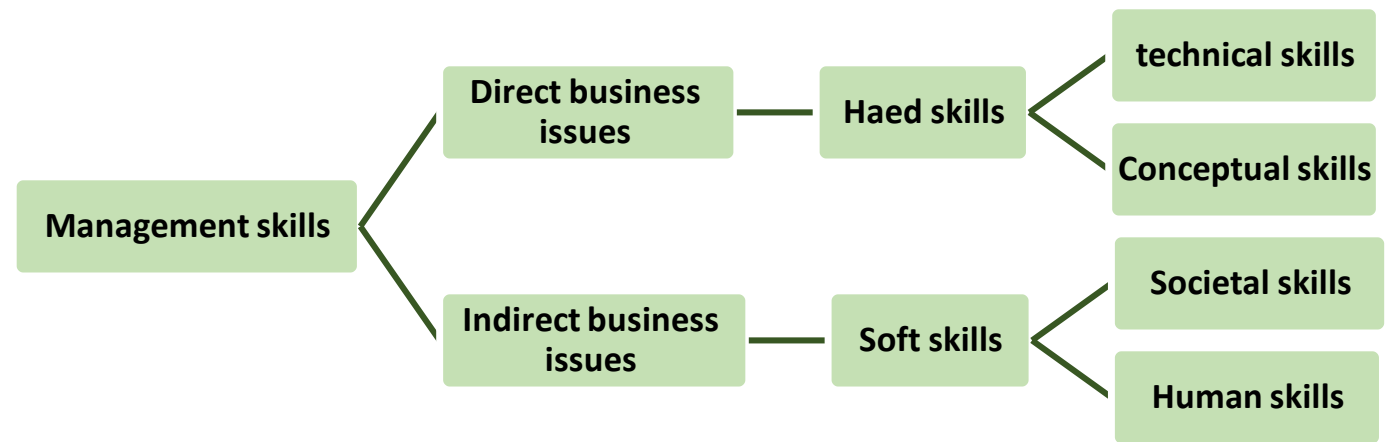

Figure 3. Management skills (adapted from Poisson-de Haro \& Turgut, 2012)

It is important to note that no specialist is recruited for transfer of information and knowledge in the organization, but it is created and spread by individuals within the organization (Ruth,

Salamzadeh, YousefNia, Markovic \& Salamzadeh

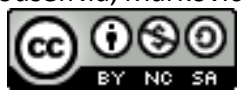

Revista Economía y Sociedad by Universidad Nacional is licensed under a CreativeCommons Reconocimiento-NoComercial- 
2006). One categorization of competency of managers includes: leadership, communication skills, moral values, personality traits, knowledge and awareness. Another categorization of competency of managers includes: leadership skills, general skills, personal skills, communication skills, creativity and personality traits (Thornton \& Byham, 1982).

Ghaffarian \& Gaffarian, (2000) puts managerial competencies into six categories: (i) Professional knowledge, (ii) skills (behavioral and intellectual skills), (iii) personality traits (self-esteem, extroversion), (iv) attitude (values and fundamentalism), (v) professional accreditation (formal communications and strong and professional power), and (vi) public Credit (informal communication, public reputation). It must be noted that in the model in this study, the category of managers' competence provided by Ghaffarian is used.

\section{The strategy schools}

Since 1970, research on the processes of strategy has focused on challenge of strategy formulation and implementation. The main topics of research in the strategy processes are making strategic decisions, defining strategies and making policies of organizations. There are many solutions from formulation of strategy schools such as those of Henry Mintzberg, Bruce Ahlstrand and Joseph Lampel. The learning school is one of ten formulated schools. According to the learning school, the trial and error learning strategy can be achieved in the organization. This issue indicates that the behavioral patterns of strategies inherently existing in the organization. The Mintzberg's classification is a comprehensive and well-known classification that knows the strategy consisting of ten schools. (Abraham et al., 2015) that is presented in Table 2.

Table 2.

The ten strategic schools of thought

\begin{tabular}{lll}
\hline School & Type of process & Tone \\
\hline Design & Conception & Prescriptive \\
Planning & Formal & Prescriptive \\
Positioning & Analytical & Prescriptive \\
Entrepreneurial & Visionary & Descriptive \\
Cognitive & Mental & Descriptive \\
Learning & Emergent & Descriptive \\
Power & Negotiation & Descriptive \\
Cultural & Collective & Descriptive \\
Environmental & Reactive & Descriptive \\
Configuration & Transformation & Integrative \\
\hline
\end{tabular}

8

Salamzadeh, YousefNia, Markovic \& Salamzadeh

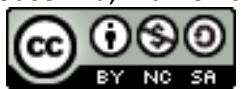

Revista Economía y Sociedad by Universidad Nacional is licensed under a CreativeCommons Reconocimiento-NoComercialCompartirlgual 4.0 Internacional License.

Creado a partir de la obra en http://www.revistas.una.ac.cr/index.php/economia 


\subsection{The learning school}

This school is originally presented by Charles Lindblom in 1959. The constructive approach to learn in uncertain situations is changing and innovation. No one knows the solution and there is also no expert to transfer knowledge and information. The solution should be created by individuals within an organization. The learning is a process of group training and is problemsolving where it is emphasized on practical development. The learning in practice regularly provides a challenging environment in which individuals raise the level of organizational knowledge with sharing their experiences with others and their former teachings (Pauleen, Corbitt \& Yoong, 2007). The learning school is a new form of communication within the organization, where managers and employees learn through using experience and practice. Mintzberg et al. (1998) suggested that a productive learning culture, is committed to the renewal of research aimed to develop and adapt ways of thinking to improve efficiency in the organization (Kenny, 2006). However, the field of learning school was created in the book of strategy for change James Brain Quinn in 1980. From that time, many schools have emerged that have been effective in the mainstream of strategic management.

The learning school is one of the most sophisticated descriptive schools. The school begins with method based on a series of small and sometimes unplanned process. This method moves step by step with small changes in a time period. Such changes are necessary to make significant changes. In this school, Individuals learn how to understand the situation and respond to changes in an organization's. The idea of learning itself may be simple, but its implementation is not as simple. The central point of this school is individual and collective values, knowledge, experience and efforts to form a strategy. Individuals training is made about terms and capabilities of organization, such behavior can be changed to strategy. Pelling in 2004 claimed strategy is a network of knowledge in which Individuals continue to progress in order to respond to anomalies. He suggests learning school is focused on the experience that later his claim was criticized by Mintzberg. Quinn also presented a mechanism that leads to a sudden strategy. In this school, learning school approach in strategy formation is presented through education and training.

The organizations learn through the evaluation of their behavioral pattern and by entering new markets and understanding the strengths and weaknesses. As part of the learning process, Mintzberg extended an applicable strategy with a holistic approach. Research conducted by Steve French in learning school concludes that a strategy is extended by a process of organizational learning (Abraham et al., 2015). The learning school, such as institution school is educational and one can say in general the concepts of learning school is common in parts of the institutional school. (Salamzadeh, Azimi \& Kirby, 2013; Chandler \& Hwang, 2015)

Salamzadeh, YousefNia, Markovic \& Salamzadeh

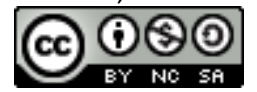

Revista Economía y Sociedad by Universidad Nacional is licensed under a CreativeCommons Reconocimiento-NoComercialCompartirlgual 4.0 Internacional License.

Creado a partir de la obra en http://www.revistas.una.ac.cr/index.php/economia 


\subsection{The learning school and manager's competences}

Research on learning of managers is in response to two main issues. One is criticism of the managers' training and demand for more research on it and the other it is the lack of well trained teachers for managers that they know the need to design high quality training programs (Thorne \& Wright, 2005). Without any doubt, management and leadership are the main resources of achievement to the expected results in organization. Recognizing that the comprehensive knowledge can exist in the mind of a person requires a different approach to create an overview of the existing status. Many of today's innovations sometimes have been marginal and trivial matters. The organization's ability to develop and incorporate different opinions, leads to knowledge survival of organization. Top management should identify and use continuous improvement through continuous learning as one of organizational strategies (Siemens, 2005). The business requires individuals with necessary understanding in development and further skills (Cheng et al., 2004).

The Identification of competencies and learning process in managers needs effective investigation in complex organizations with different environments. In the learning process of managers, the capacity of members is expanded and is aligned in such a way that the results are what everyone really wants it. In this regard, the learning school is a crucial step in improving the managers' competency and creating leading organizations. In the following we discuss the influence of learning school in six key managerial competencies we will rank them (Kolb et al., $\underline{1986)}$.

Table 3.

\section{Literature review}

\begin{tabular}{lll}
\hline Article & Researcher/Year & Results \\
\hline $\begin{array}{l}\text { Connectivism: A Learning Theory } \\
\text { for the Digital Age }\end{array}$ & Siemens, G. $\underline{2005}$ & $\begin{array}{l}\text { An organizations ability to foster, nurture, and } \\
\text { synthesize the impacts of varying views of information } \\
\text { is critical to knowledge economy survival. Speed of } \\
\text { "idea to implementation" is also improved in a } \\
\text { systems view of learning. }\end{array}$ \\
$\begin{array}{l}\text { Developing strategic alliances in } \\
\text { management learning }\end{array}$ & $\begin{array}{l}\text { Thorne, E., \& } \\
\text { Wright, G. } \underline{2005}\end{array}$ & $\begin{array}{l}\text { Management learning is described as an area of both } \\
\text { professional practice and theoretical enquiry. }\end{array}$ \\
$\begin{array}{l}\text { Managerial competencies for } \\
\text { middle managers: some empirical } \\
\text { findings from China }\end{array}$ & $\begin{array}{l}\text { Qiao, J., \& Wang, } \underline{2009} \\
\text { The }\end{array}$ & $\begin{array}{l}\text { The top five most important competencies for middle } \\
\text { managers are included accountability, team building, } \\
\text { relationship management, continual learning and } \\
\text { conflict management. }\end{array}$ \\
$\begin{array}{l}\text { A Guide For Development And } \\
\text { Coaching }\end{array}$ & $\begin{array}{l}\text { Lombardo, M., \& } \\
\text { Eichinger. R, W. }\end{array}$ & $\begin{array}{l}\text { Managerial performances are the main one and it } \\
\text { controls the others, because it can generate the } \\
\text { proper intern conditions for them to develop. }\end{array}$
\end{tabular}

10

Salamzadeh, YousefNia, Markovic \& Salamzadeh

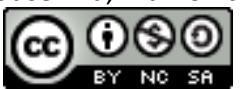

Revista Economía y Sociedad by Universidad Nacional is licensed under a CreativeCommons Reconocimiento-NoComercialCompartirlgual 4.0 Internacional License. Creado a partir de la obra en http://www.revistas.una.ac.cr/index.php/economia 


\begin{tabular}{|c|c|c|}
\hline Article & Researcher/Year & Results \\
\hline $\begin{array}{l}\text { Managerial Core Competencies as } \\
\text { Predictors of Managerial } \\
\text { Performance, on Different Levels } \\
\text { of Management }\end{array}$ & Bucur, I. $\underline{2013}$ & $\begin{array}{l}\text { For intervention regarding improving the performance, } \\
\text { all the competencies can be utilised, but the most } \\
\text { useful is the learning competence }\end{array}$ \\
\hline $\begin{array}{l}\text { Expanded strategy simulations: } \\
\text { developing better managers }\end{array}$ & $\begin{array}{l}\text { Poisson-de Haro, S. } \\
\text { \& Turgut, G. } \underline{2012}\end{array}$ & $\begin{array}{l}\text { While managers need greater integration abilities, the } \\
\text { delivery of the strategy course has barely changed for } \\
\text { decades. With its interactive stance toward learning, } \\
\text { experiential learning is an ideal method for } \\
\text { management learning, particularly in teaching } \\
\text { business strategy. }\end{array}$ \\
\hline $\begin{array}{l}\text { Assessment centers and } \\
\text { managerial performance }\end{array}$ & $\begin{array}{l}\text { Thornton, G., \& } \\
\text { Byham, W. } 1982\end{array}$ & $\begin{array}{l}\text { A list of competencies of senior managers have } \\
\text { identified as follows: leadership skills, general skills } \\
\text { management, personal skills, communication skills, } \\
\text { creativity, personality traits such as trust, reliability } \\
\text { and compatibility }\end{array}$ \\
\hline Managerial Competencies & Ghaffrian, V. $\underline{2000}$ & $\begin{array}{l}\text { Management components placed in six groups : } \\
\text { Professional knowledge-skill -personality traits - } \\
\text { Attitude -professional credit-Public Credit }\end{array}$ \\
\hline
\end{tabular}

\section{Methodology}

The study, in terms of type and purpose, is an applied research and in terms of nature and methods, is descriptive survey research. The main variable is the improvement of managers' competency in one of the state banks of Iran- Saderat Bank. In the development of literature and theoretical research, the data collection was carried out through library studies and documents review by studying texts, articles, books and resources related to the field of strategic management, learning, competency in employees and managers of organizations. The study was conducted at various levels of the Saderat Bank in order to investigate the learning school among ten schools of strategy in the organization and its role in factors influencing the improvement of managers' competency and the contribution of each factor. The study population included all executive, middle and senior managers (line and staff) in the bank in the geographic area of the Tehran. By using Morgan's table, assuming the infinite population the sample size (confidence level of $95 \%$ and error level of 5\%) were determined to be 362 . Thus, 400 questionnaires were distributed randomly and 384 Individuals were selected. Then, the effect of learning school on six core managerial competencies is analyzed and the items are ranked accordingly.

First, a questionnaire to collect data in the form of 47 questions was prepared which the first part was related to the personal information of samples and questions 1 to 20 were related on how to implement learning school in the organization and the final 27 questions were related to the analyzing and weighting the criteria of managers' competencies. The experts, managers in the field as a judge, confirmed the validity of questionnaire. After confirmation, the validity, the

Salamzadeh, YousefNia, Markovic \& Salamzadeh

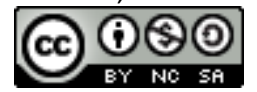

Revista Economía y Sociedad by Universidad Nacional is licensed under a CreativeCommons Reconocimiento-NoComercialCompartirlgual 4.0 Internacional License. Creado a partir de la obra en http://www.revistas.una.ac.cr/index.php/economia 
questionnaire was distributed in the statistical population. First in-person, the necessary explanations in relation to answer to the questionnaire were given and they were asked to answer the questions accurately. The questions of 20 to 47 in order to calculate the effect of learning school in each of the components of managers' competency were considered and then were analyzed. After collecting answers, it was allocated the specialized score from 1 to 5 by samples to each factor.

\section{Conceptual model}

The research model is as follows.

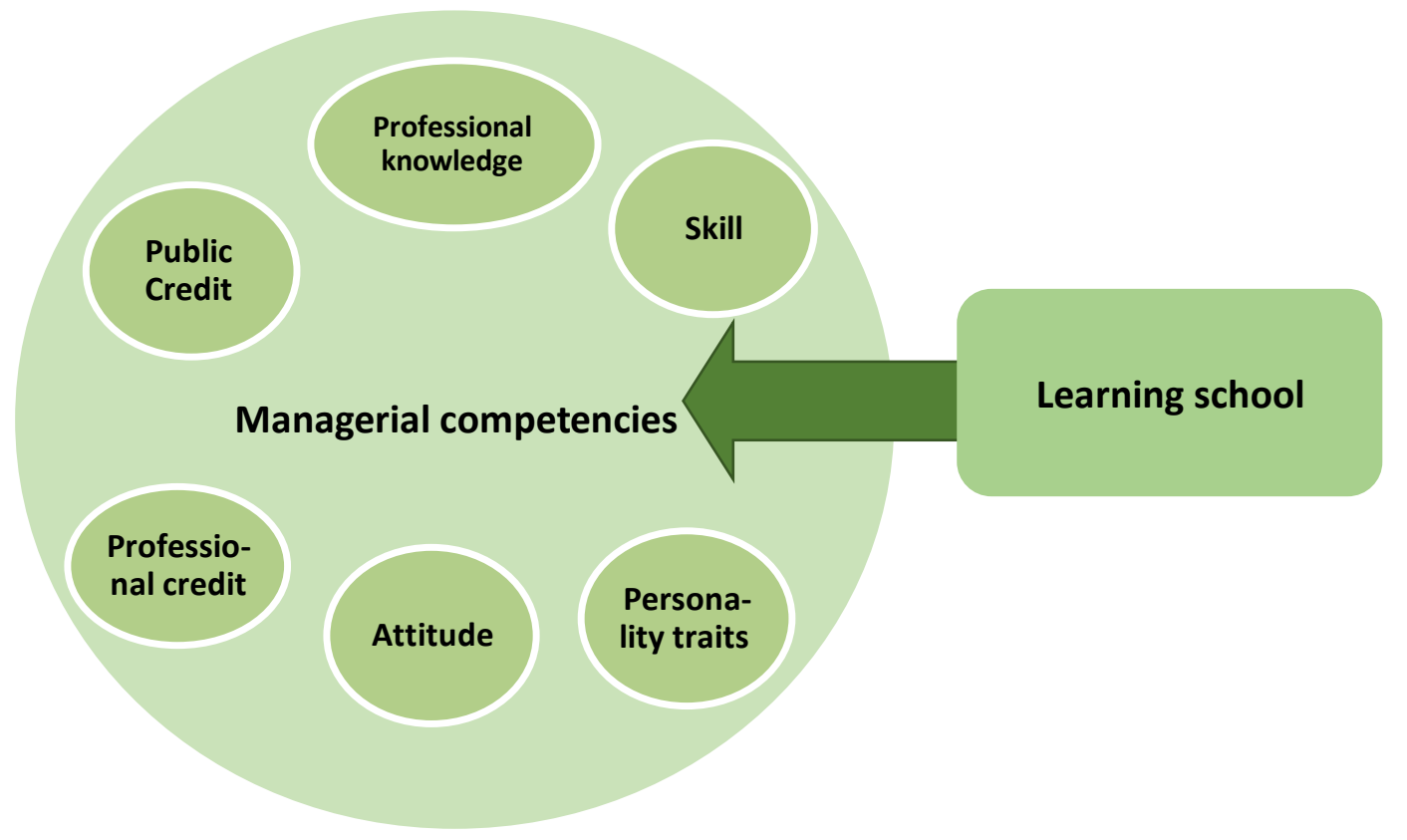

Figure 4. Research model

\subsection{Hypotheses}

\section{Main hypothesis}

$\mathbf{H}$ : There is a significant relationship between implementation of learning school in organization and improvement of managers' competencies.

12 


\section{Other hypotheses}

H1: There is a significant relationship between implementation of learning school in organization and capabilities of managers.

H2: There is a significant relationship between implementation of learning school in organization and professional knowledge of managers.

H3: There is a significant relationship between implementation of learning school in organization and public credit of managers.

H4: There is a significant relationship between implementation of learning school in organization and professional credit of managers.

H5: There is a significant relationship between implementation of learning school in organization and attitudes of managers.

H6: There is a significant relationship between implementation of learning school in organization and personality traits of managers.

The independent variable of this study is the implementation of learning school in organization and its contribution and effectiveness on the dependent variable i.e. competency of managers and each of its components i.e. the capabilities, professional knowledge and public credit, professional credit, attitude, and personality traits was calculated. Factors influencing the competency of managers are briefly described as follows:

- Capabilities: The ability to perform a specific job is physical or mental. The ability to implement the knowledge in practice, results in the improvement of performance quality. Without this ability in many cases the manager knowledge will not be effective (Spencer \& Spencer, 1993).

- Professional knowledge: the theoretical knowledge is the oldest dimension of managers' development. The theoretical training broadens the manager's knowledge about the related issues. This competency is considered the infrastructure of the development of capabilities and attitudes, but in many cases, does not in itself have much effect on the development of managerial competencies (Ghaffrian, 2000).

- Public credit: the public credit of a manager is related to his non-professional position in the society. The fact is that business and public life of a manager interact with each other and management of both is not possible separately.

Salamzadeh, YousefNia, Markovic \& Salamzadeh

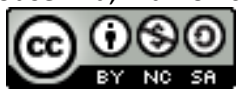

Revista Economía y Sociedad by Universidad Nacional is licensed under a CreativeCommons Reconocimiento-NoComercial- 
- Professional credit: it has an important role in creating business networks and attracts their cooperation in the implementation of organization programs. It is a managerial intangible asset that one has no choice but to construct social relationships with Individuals in the society, so that all Individuals looking for a specific purpose make ongoing efforts (Hosmer, 1991).

- Attitudes and insights: it is the mental image of human from his world and environment. The mental image is a framework that explains and shapes the field of his thought and action. The understanding of human from the phenomenon around himself his decision to act, is based on his mental image.

- Personality traits: the personality is a set of stable behavioral, emotional, and intellectual and unique patterns that Individuals show it. The personality is a combination of psychological traits which Individuals are classified in this way. The psychological proportionality of individual with his job is considered an important factor (Ghaffrian, 2000).

\section{Results}

After collecting the questionnaires and data entry in SPSS statistical software, the individual characteristics of the samples were identified as Table 4.

Table 4.

The individual characteristics of samples

\begin{tabular}{|c|c|c|c|c|c|}
\hline \multirow[t]{2}{*}{ Age } & Less 35 & $35-45$ & $45-55$ & Up 55 & Total \\
\hline & 256 & 102 & 26 & 0 & 384 \\
\hline \multirow[t]{2}{*}{ Education } & Diploma & Bachelors & Masters & P.H.D & Total \\
\hline & 14 & 246 & 112 & 12 & 384 \\
\hline \multirow[t]{2}{*}{ String } & Technical & Humanities & Science & Other & Total \\
\hline & 281 & 97 & 0 & 6 & 384 \\
\hline \multirow[t]{2}{*}{ work experience } & Less 10 & $10-20$ & \multicolumn{2}{|c|}{ Up 20} & Total \\
\hline & 256 & 102 & \multicolumn{2}{|c|}{26} & 384 \\
\hline \multirow[t]{2}{*}{ Initiation } & Deal & Official & \multicolumn{2}{|c|}{ Other } & Total \\
\hline & 205 & 128 & \multicolumn{2}{|c|}{51} & 384 \\
\hline \multirow[t]{2}{*}{ Sex } & \multicolumn{2}{|c|}{ Male } & \multicolumn{2}{|c|}{ Female } & Total \\
\hline & \multicolumn{2}{|c|}{275} & \multicolumn{2}{|c|}{109} & 384 \\
\hline \multirow[t]{2}{*}{ Status } & \multicolumn{2}{|c|}{ Single } & \multicolumn{2}{|c|}{ Married } & Total \\
\hline & \multicolumn{2}{|c|}{77} & \multicolumn{2}{|c|}{307} & 384 \\
\hline
\end{tabular}

14

Salamzadeh, YousefNia, Markovic \& Salamzadeh

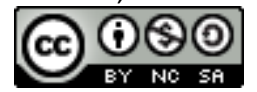

Revista Economía y Sociedad by Universidad Nacional is licensed under a CreativeCommons Reconocimiento-NoComercialCompartirlgual 4.0 Internacional License. Creado a partir de la obra en http://www.revistas.una.ac.cr/index.php/economia 
Then the data related to main questions of questionnaires were entered in the statistical software. The first 20 questions were related to implementation of learning school and 21-25 to capabilities, $26-29$ to professional knowledge, $30-32$ to public credit, 33 - 36 to professional credit, questions 37 - 42 to attitude, 43 - 47 to personal traits criteria. Then the Cronbach's alpha coefficient was measured by the amount of 0.927 which confirmed very much the reliability or validity of the questionnaires (Figure 5 ).

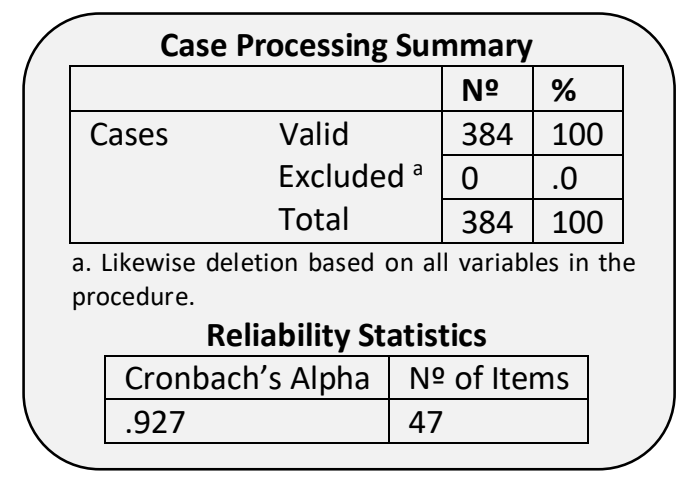

Figure 5. Cronbach's alpha test.

After this step, the Kolmogorov-Smirnov test was carried out for investigation of whether or not the data are not normal and it was determined that the data are not normal and must be used nonparametric tests (Figure 6).

\begin{tabular}{|c|c|c|c|c|c|c|c|c|c|c|c|c|c|c|}
\hline & & q1 & q2 & q3 & $q 4$ & q5 & q6 & q7 & q8 & q9 & q10 & q11 & q12 & q13 \\
\hline \multicolumn{2}{|l|}{$\mathrm{N}$} & 384 & 384 & 384 & 384 & 384 & 384 & 384 & 384 & 384 & 384 & 384 & 384 & 384 \\
\hline \multirow{2}{*}{$\begin{array}{l}\text { Normal } \\
\text { Parameters a,b }\end{array}$} & Mean & 1.80 & 2.61 & 2.24 & 2.37 & 2.59 & 2.61 & 2.20 & 2.59 & 2.49 & 2.25 & 2.13 & 2.68 & 3.01 \\
\hline & $\begin{array}{l}\text { Std. } \\
\text { Deviation }\end{array}$ & .401 & .890 & .957 & .949 & .927 & 1.059 & 1.032 & .669 & .903 & 1.021 & 1.035 & 1.075 & .957 \\
\hline \multirow{3}{*}{$\begin{array}{l}\text { Most Extreme } \\
\text { Differences }\end{array}$} & Absolute & .491 & .272 & .207 & .213 & .224 & .255 & .245 & .299 & .235 & .191 & .215 & .243 & .225 \\
\hline & Positive & .308 & .197 & .179 & .213 & .185 & .152 & .245 & .299 & .185 & .183 & .215 & .223 & .221 \\
\hline & Negative & -.491 & -.272 & -.207 & -.185 & -.224 & -.255 & -.142 & -.243 & -.235 & -.191 & -.138 & -.243 & -.225 \\
\hline \multicolumn{2}{|c|}{ Test Statistics } & .491 & .272 & .207 & .213 & .224 & .255 & .246 & .299 & .235 & .191 & .215 & .243 & .225 \\
\hline \multicolumn{2}{|c|}{ Asym Sig. (2-tailed) } & $.000^{\mathrm{a}}$ & $.000^{\mathrm{a}}$ & $.000^{\mathrm{a}}$ & $.000^{\mathrm{a}}$ & $.000^{\mathrm{a}}$ & $.000^{\mathrm{a}}$ & $.000^{\mathrm{a}}$ & $.000^{\mathrm{a}}$ & $.000^{\mathrm{a}}$ & $.000^{\mathrm{a}}$ & $.000^{\mathrm{a}}$ & $.000^{\mathrm{a}}$ & $.000^{\mathrm{a}}$ \\
\hline
\end{tabular}

Figure 6. Kolmogorov-Smirnov test

In the next step, using the Spearman test there was a significant relationship between learning school and 5 competency criteria in managers. But there was not a significant relationship between the implementation of learning school and its effect on the personality criterion in managers (Figure 7). 


\section{Nonparametric Correlations}

\begin{tabular}{|c|c|c|c|c|c|c|c|c|c|}
\hline \multicolumn{10}{|c|}{ Correlations } \\
\hline & & & P1 & $\mathrm{P} 2$ & P3 & P4 & P5 & P6 & P7 \\
\hline \multirow[t]{5}{*}{ Spearman's rho } & \multicolumn{2}{|c|}{ Correlation Coeeficient } & 1.000 & $.182^{* *}$ & .055 & $-.222^{* *}$ & $-.143^{* *}$ & $.357^{* *}$ & -.047 \\
\hline & \multicolumn{2}{|c|}{ Sig. (1-tailed) } & & .000 & .001 & .000 & .003 & .000 & .180 \\
\hline & \multicolumn{2}{|c|}{$\mathrm{N}$} & 384 & 384 & 384 & 384 & 384 & 384 & 384 \\
\hline & \multirow[t]{2}{*}{ Bootstrap $^{b}$} & Bias & .000 & .000 & .000 & .000 & .000 & .000 & .000 \\
\hline & & $\begin{array}{l}\text { Std. } \\
\text { Error }\end{array}$ & .000 & .000 & .000 & .000 & .000 & .000 & .000 \\
\hline
\end{tabular}

Figure 7. Spearman test

In the next test, the regression test (Figure 8) was used to model the relationship between variables, and the regression equation was obtained between independent variables and dependent variables in following formula:

$$
E(Y \mid x 1, x 2, \ldots, x k)=a 0+a 1 x 1+a 2 x 2+\cdots+a k x k
$$

The implementation of learning school $=2.970+0.005$ (capability) +0.022 (knowledge) -0.262 (public credit) - 0.165 (professional credit) +0.400 (attitude) +0.012 (knowledge)

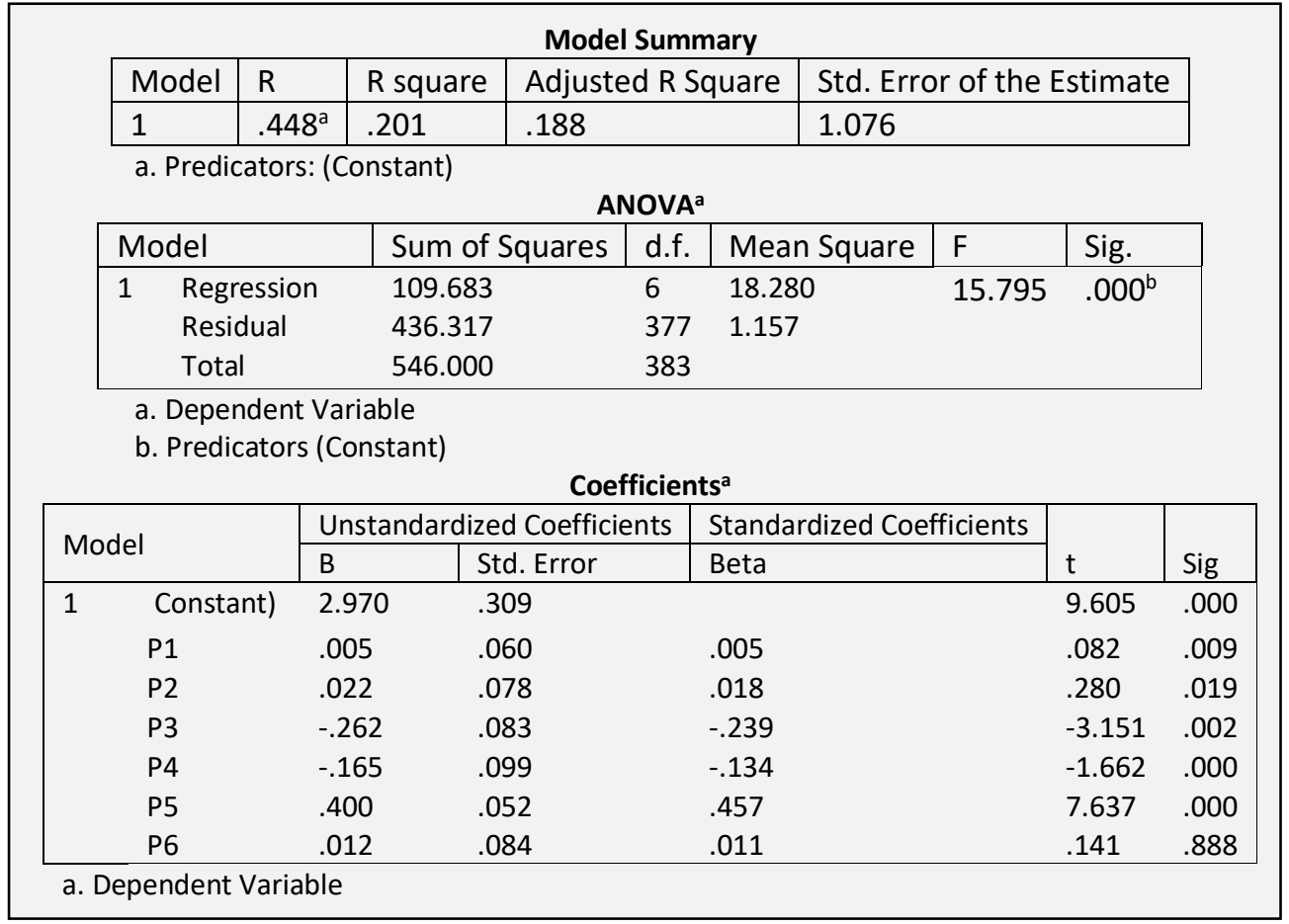

Figure 8. Multiple linear regression test

16

Salamzadeh, YousefNia, Markovic \& Salamzadeh

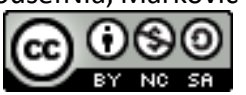

Revista Economía y Sociedad by Universidad Nacional is licensed under a CreativeCommons Reconocimiento-NoComercialCompartirlgual 4.0 Internacional License.

Creado a partir de la obra en http://www.revistas.una.ac.cr/index.php/economia 
As shown in Figure 8, there is a significant relationship between all criteria and learning school except personality criterion. Finally, by using Topsis method, the effectiveness of each competencies of learning school was ranked as follows (Table 5):

Table 5.

The ranking of managers' competency criteria in terms of the effectiveness of learning school

\begin{tabular}{|c|c|c|c|c|c|c|c|c|}
\hline Rank & Index & Relation & \multicolumn{2}{|c|}{ cli } & \multicolumn{2}{|c|}{ di - } & \multicolumn{2}{|c|}{$d i+$} \\
\hline 1 & Public Credit & \multirow{2}{*}{ Reverse } & 0.352 & cl 1 & 1.566 & d1 - & 2.879 & $\mathrm{~d} 1+$ \\
\hline 2 & Professional credit & & 0.597 & $\mathrm{cl} 2$ & 2.505 & d2 - & 1.693 & $\mathrm{~d} 2+$ \\
\hline 3 & Attitude & \multirow{4}{*}{ straight } & 0.728 & $\mathrm{cl} 3$ & 3.03 & d3 - & 1.141 & $\mathrm{~d} 3+$ \\
\hline 4 & Professional knowledge & & 0.696 & $\mathrm{cl} 4$ & 2.877 & d4 - & 1.259 & d4 + \\
\hline 5 & Skill & & 0.644 & cl 5 & 2.705 & d5 - & 1.496 & d5 + \\
\hline 6 & Personality traits & & 0.208 & $\mathrm{cl} 6$ & 0.849 & d6 - & 3.235 & d6 + \\
\hline
\end{tabular}

Concerning the ranking of table 5, the mention of some points seems necessary. First place, the attitude criterion in terms of direct effectiveness from learning school as a framework which explains the field of though and action in manager and his decision to act, on the basis of his mental image shapes him, is explained in this way that learning and experience from others, improves person's ability to respond to a particular situation and it can be concluded that the expansion of learning school especially in staff departments to train competent managers is very important and given the current organizational culture of banking systems this result is not unexpected because individuals in staff departments are trained and future managers of branches are elected among them (Salamzadeh, Salamzadeh, \& Radovic-Markovic, 2016). The professional knowledge, capability, personality traits, was placed in the next rankings of direct effectiveness.

Learning in the organization increases the person's level of knowledge considerably and this is more manifested in management positions. Regardless of the position of human resources in achieving strategic objectives, organizational efficiency is primarily the result of several factors which one of the most important of them is the improvement of employee's knowledge. Learning also has an important role in the improvement of technical, human and conceptual capabilities of managers and the outcome of the above ranking clearly reveals this point. The personality traits criterion given that these traits are usually stable and rarely influenced by other factors was placed at the bottom of the above ranking. But the inversely relationship between public credit and professional credit criteria can also be explained in this way that the credit in managers, is not acquired and is reliability, it is unique to everyone and does not need not only to education and gain experience, but also reduces the credibility of individuals. The results are shown schematically in Figure 9. 


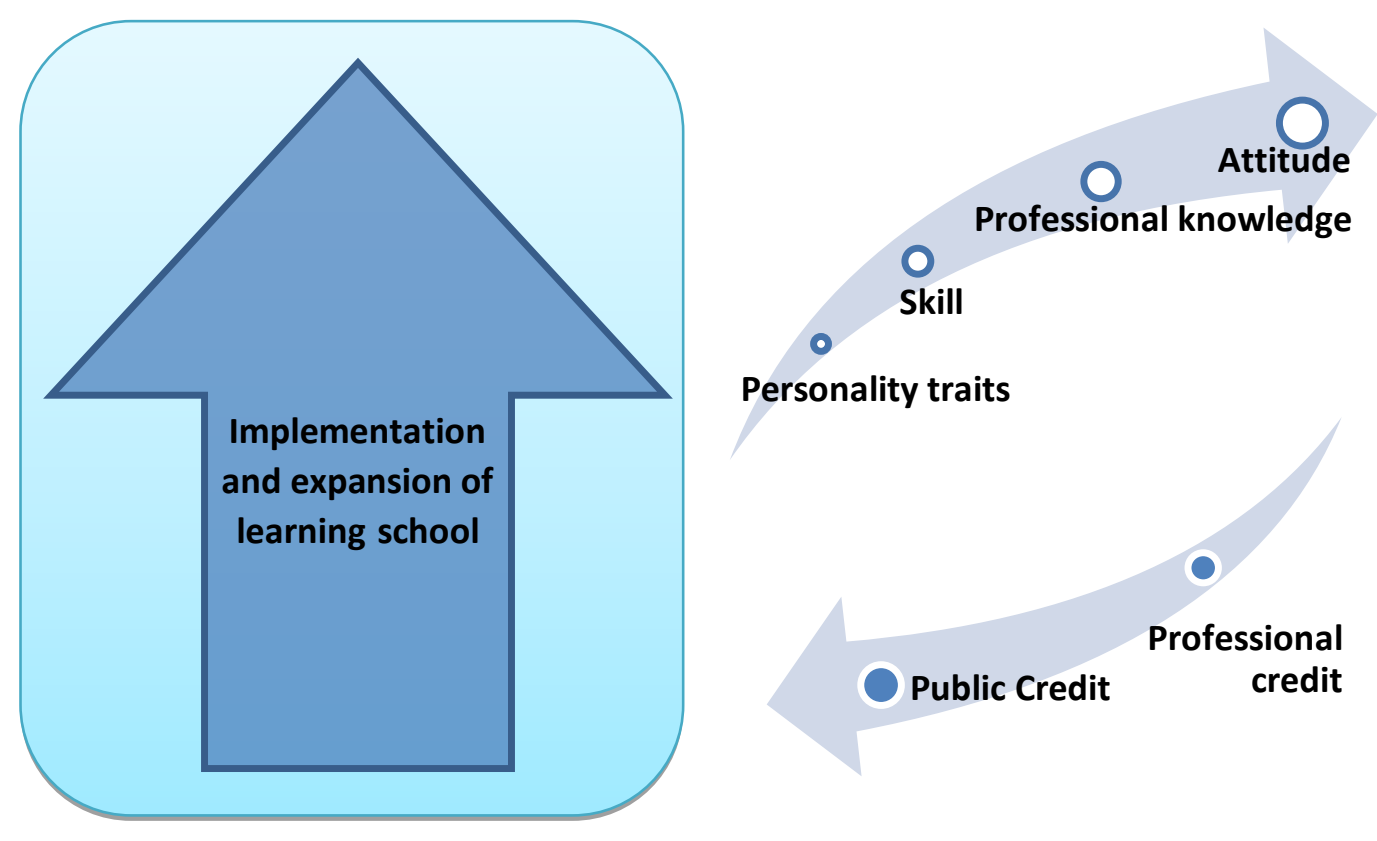

Figure 9. Schematic model of the effect of learning school implementation on managers' competencies

\section{Discussion and conclusions}

Knowledge development and capabilities of human resources, especially in the world of current developments is essential and necessary, because increasing the human resource capabilities in quantitative and qualitative improvement of products and services plays a major role and finally it is effective in achieving strategic objectives and public satisfaction. For an organization to be remained stable and leading, in the area of today's economic activities, it must be familiar with time requirements and according to these requirements pave its way towards the future. One of the most important issues that organizations today need more than ever to pay attention is the issue of education and learning. What is more important now, is that managers rely on their capabilities for using expert and technical powers in applying efficient management on employees. Basically, when employees recognize that their superior managers have experience and comprehensive professional knowledge of the technical affairs of the organization, a state of acceptance and respect for their superiors is created that facilitate and accelerate the organizational administration and when employees feel that they are under management of someone who technically detects the obstacles and problems in the organization and has the ability to resolve them, they will easily follow him. A large tank of water until the fresh water although the in the size of narrow stream, but always not enters and leave it, will be eventually dry up and on the other hand, even if water leaves not out, if a source of fresh water is not 18

Salamzadeh, YousefNia, Markovic \& Salamzadeh

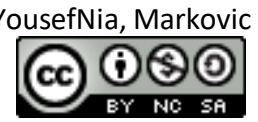

Revista Economía y Sociedad by Universidad Nacional is licensed under a CreativeCommons Reconocimiento-NoComercial- 
streamed will become stagnant and unusable. Therefore, what can result in the successfulness of managers in ongoing and effective use of power source of experiences and expertise gained over the years of service in bank will be their combination with new knowledge and expertise in the banking industry (Jafari, Salamzadeh, \& Yousefiyar, 2014).

In this study, in addition to a brief look on the learning and the implementation of learning school in organization, the six criteria influencing the managers competencies (capabilities, professional knowledge, public credit, professional credit, attitude and insight, personality traits) and the effectiveness of learning school from ten schools of strategy on these criteria are investigated in one of state banks of Iran. The results indicate the significant relationship between all criteria (except for personality traits) and learning school. Also previous studies in this regard such as Thorne \& Wright (2005), Lombardo \& Eichinger (2004), Poisson-de Haro \& Turgut (2012), Kolb et al. (1986) and Siemens (2005), concerning the learning school and its effect on the criteria of competency in managers were confirmed.

\section{Recommendation}

According to the obtained results it is suggested that for achieving clearer results, similar studies be carried out with the following topics: (i) A research should be carried out on the effect of learning school or ten schools of strategies in competency criteria at expert level in the field of various economic activities to extend the results of this research, (ii) The results of this current study and similar researches for decision-making, selection and appointment and improvement of country's managers should be available for senior managers of economic organizations, (iii) A research should be carried out to implement the criteria influenced by the implementation of learning school in the periodic performance evaluation model of organization employees and formulation of new model for it according to the results of this research and given weighting in it, (iv) The results of this research should be used to prepare and implement the instruction of attraction and employing competent managers, and ( $v$ ) A research in the field of automotive industry with similar issue of this research should be conducted and its results be compared with this research.

\section{References}

Abraham, O., Sarbah, A., and Abrokwah, E., (2015). The Applicability of the Learning School Model of Strategy Formulation (Strategy Formulation as an Emergent Process), Open Journal of Business and Management, 3(2), 135-154. https://doi.org/10.4236/ojbm.2015.32014

Bao, G. (2015). What theories are needed for strategic management?. Business Review International, 6(4), 433-454. doi: https://doi.org/10.1108/nbri-05-2015-0012

Salamzadeh, YousefNia, Markovic \& Salamzadeh

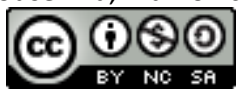

Revista Economía y Sociedad by Universidad Nacional is licensed under a CreativeCommons Reconocimiento-NoComercialCompartirlgual 4.0 Internacional License. Creado a partir de la obra en http://www.revistas.una.ac.cr/index.php/economia 
Beveridge, M., Gear, E.A., \& Minkes, A. (1997). Organizational learning and strategic decision support. The Learning Organization, 4(5), 217-227. https://doi.org/10.1108/09696479710186403

Bucur, I., (2013). Managerial Core Competencies as Predictors of Managerial Performance, on Different Levels of Management. Procedia-social and behavioral sciences, 78, 369-365. doi: https://doi.org/10.1016/i.sbspro.2013.04.312

Chandler, D., \& Hwang, H. (2015). Learning from Learning Theory: A Model of Organizational Adoption Strategies at the Microfoundations of Institutional Theory. Journal of Management, 41(5), 1446-1476. doi: https://doi.org/10.1177/0149206315572698

Cheng, W.L. Li, H., Love, P., \& Irani, Z. (2004). A learning culture for strategic partnering in construction. Construction Innovation, 4(1), 53-65. https://doi.org/10.1108/14714170410815006

Chyung S.Y., Stepich D, \& Cox D., (2006). Building a competency-based curriculum architecture to educate 21st-century business practitioners. Journal of Education for Business, 81(6), 307-314. doi: https://doi.org/10.3200/joeb.81.6.307-314

Ghaffarian, V., Ghaffarian, F. (2000). Managerial Competencies: How You Could Manage an Organization. Industrial Management Organization: Tehran: Iran. Retrieved form www.adinehbook.com/gp/product/9648896770

Gottfredson, L. (2002). Where and why g matters: Not a mystery. Human Performance, 15(1), 25-46. Retrieved from https://www1.udel.edu/educ/gottfredson/reprints/2002notamystery.pdf

Hosmer, L. T. (1991). The ethics of management. McGraw-Hill Education; 7 edition. ISBN: 9780073530543

https://www.amazon.com/Ethics-Management-RueHosmer/dp/0073530549

Hoffmann, T. (1999). The meanings of competency'. Journal of European Industrial Training, 23(6), 285-275. https://doi.org/10.1108/03090599910284650

Jafari, S., Salamzadeh, A., \& Yousefiyar, A. (May, 2014). Factors Affecting Senior Managers' Entrepreneurial Behavior in Iranian Pioneer Banks. In Proceedings of International Conference on Entrepreneurship (ICE), Tehran, Iran. Retrieved from https://papers.ssrn.com/sol3/papers.cfm?abstract id $=2432980$ 
Jennings, D. (2002). Strategic Management: An evaluation of the use of three learning methods. Journal of Management Development, 21(9), 655-665. doi: https://doi.org/10.1108/02621710210441658

Kenny, J. (2006). Strategy and the learning organization: a maturity model for the formation of strategy. The Learning Organization, 13(4), 353-368. doi: https://doi.org/10.1108/09696470610667733

Khajeheian, D. (2013). New Venture Creation in Social Media Platform: Towards a Framework for Media Entrepreneurship. Handbook of Social Media Management (pp. 125-142). doi: https://doi.org/10.1007/978-3-642-28897-5 8

Kolb, D., Lublin, S., Spoth, J., \& Baker, R. (1986). Strategic Management Development: Using Experiential Learning Theory to Assess and Develop Managerial Competencies'. Journal of Management Development, 5(3), 13-24. doi: https://doi.org/10.1108/eb051612

Lane, G., \& Robinson, A. (1995). The development of standards of competence for senior management. Executive Development, 8(6), 4-8. doi: https://doi.org/10.1108/09533239510095475

Liljenberg, M. (2015). Distributing leadership to establish developing and learning school organisations in the Swedish context. Educational Management Administration \& Leadership, 43(1), 152-170. doi: https://doi.org/10.1177/1741143213513187

Lombardo, M., \& Eichinger. R, W. (2004). FYI: For Your Improvement: A Guide for development and Coaching. Lominger Ltd Inc; 4th edition. Retrieved from https://www.amazon.com/FYI...Guide-Development-Coaching/dp/0974589233

McClelland, J. L. (1976). Preliminary letter identification in the perception of words and nonwords.Journal of Experimental Psychology: Human Perception and Performance, 2(1), 80-97. doi: https://doi.org/10.1037//0096-1523.2.1.80

McHugh, D., Groves, D., \& Alker, A. (1998). Managing learning: what do we learn from a learning organisation?. The Learning Organization, 5(5), 209-220. doi: https://doi.org/10.1108/09696479810238215

Mintzberg, H., Ahlstrand, B., \& Lampel, J. (1998). Strategy Safari: A Guide Tour through the Wilds of Strategic Management. Retrieved from https://books.google.co.cr/books/about/Strategy Safari.html?id=xh27AAAAIAAJ\&redir esc=y 
Mišanková, M., \& Kočišová, K. (2014). Strategic implementation as a part of strategic management. Procedia-Social and Behavioral Science, 110, 861-870. doi: https://doi.org/10.1016/j.sbspro.2013.12.931

Mojab, F., Zaefarian, R., \& Dazian, A. (2011). Applying competency based Approach for Entrepreneurship education. Procedia and Behavioral Sciences, 12, 436-447. doi: https://doi.org/10.1016/i.sbspro.2011.02.054

Mumford, A. (1984). Effectiveness in management development. Journal of Management Development, 3(2), 3-16. doi: https://doi.org/10.1108/eb051556

Pauleen, D., Corbitt, B., \& Yoong, P. (2007). Discovering and articulating what is not yet known: Using action learning and grounded theory as a knowledge management strategy. The Learning Organization, 14(3), 222-240. doi: https://doi.org/10.1108/09696470710739408

Peleckis, K. (2015). Strategic management schools and business negotiation strategy of company operations, Economics and Management, 7(2), 112-119. http://yadda.icm.edu.pl/yadda/element/bwmeta1.element.baztech-e45d8f8e-1cad451e-b980-c166637fa611/c/peleckis strategic EiZ 2 2015.pdf

Poisson-de Haro, S., \& Turgut, G. (2012). Expanded strategy simulations: developing better managers. Journal of Management Development,31(3), 209-220. https://doi.org/10.1108/02621711211208844

Quaye, I., Osei, A., Sarbah, A., \& Abrokwah, E. (2015). The Applicability of the Learning School Model of Strategy Formulation (Strategy Formulation as an Emergent Process). Open Journal of Business and Management, 3, 135-154. doi: https://doi.org/10.4236/ojbm.2015.32014

Qiao, J., \& Wang, W. (2009). Managerial competencies for middle managers: some empirical findings from China. Journal of European Industrial Training, 33(1), 69-81. doi: https://doi.org/10.1108/03090590910924388

Ruth, D. (2006). Frameworks of managerial competence: limits, problems and suggestions. Journal of European Industrial Training, 30(3), 206-226. doi: https://doi.org/10.1108/03090590610662959 
Salamzadeh, A., Azimi, M. A., \& Kirby, D. A. (2013). Social entrepreneurship education in higher education: insights from a developing country. International Journal of Entrepreneurship and Small Business, 20(1), 17-34. doi: https://doi.org/10.1504/ijesb.2013.055691

Salamzadeh, A., \& Kawamorita, H. (2015). Startup Companies: Life Cycle and Challenges. 4th International Conference on Employment, Education and Entrepreneurship (EEE), Belgrade, Serbia. doi: https://doi.org/10.2139/ssrn.2628861

Salamzadeh, Y., Salamzadeh, A., \& Radovic-Markovic, M. (2016). Cultural intelligence and network organizations in society: Case of Tehran neighborhood councils'. International Review, 4(1-2), 46-58. doi: https://doi.org/10.5937/intrev1602046s

Senge, P. (1992). Mental models. Planning review, 20(2), 4-44. doi: https://doi.org/10.1108/eb054349

Siemens, G. (2005). Connectivism: A Learning Theory for the Digital Age. Retrieved from www.itdl.org/journal/jan 05/article01.htm

Spencer, L., \& Spencer, S. (1993). Competence at work: Models for Superior Performance. Retrieved from http://eu.wiley.com/WileyCDA/WileyTitle/productCd-047154809X.html

Thorne, E., \& Wright, G. (2005). Developing strategic alliances in management learning. Journal of European Industrial Training, 29(5), 383-404. doi: https://doi.org/10.1108/03090590510603423

Thornton, G., \& Byham, W. (1982). Assessment centers and managerial performance Organizational and Occupational Psychology, 371-390. doi: https://doi.org/10.1016/b978-0-12-690620-2.50015-5

Whetten, A. (1989). What constitutes a theoretical contribution? Academy of management review, 14(4), 490-495. https://doi.org/10.5465/amr.1989.4308371 